\title{
Pengaruh Pelatihan, Disiplin dan Penghargaan terhadap Kinerja Karyawan PT Bank Sinarmas di Kabupaten Bekasi
}

\author{
Suwandi \\ Universitas Pelita Bangsa \\ suwandi@pelitabangsa.ac.id \\ Grecia Sutanti \\ Universitas Pelita Bangsa \\ Grecsutanti96@gmail.com
}

\begin{abstract}
Human resources in an organization will play an effective role when driven and controlled by a workforce who has achievements. The most important factor in supporting the success of an organization or company is employee performance. High productivity will be very beneficial for both employers and employees, especially for their welfare. Various efforts that can be taken by a company to develop its human resources to encourage progress for the company are using conducting training, increasing discipline, and giving rewards to employees. The purpose of this study was to determine the effect of training, discipline, and rewards on employee performance. The sample in this study were all Sinarmas Banks in the Bekasi district, amounting to 65 people. Statistical analysis includes validity and reliability tests, classical assumption tests, and multiple linear regression with SPSS software. The results in this study explain that there is an effect of training on employee performance, the influence of discipline on employee performance, and the influence of reward on employee performance.
\end{abstract}

\section{Keywords Training, Discipline, Rewards, Employee Performance}

\section{LATAR BELAKANG}

Dilihat dari sudut manajemen, baik dalam ruang lingkup organisasi pemerintahan maupun swasta, manusia menempati posisi utama diantara sumber-sumber daya lainnya. Sumber daya manusia dalam suatu organisasi akan berperan secara efektif bila digerakkan dan dikendalikan oleh para tenaga kerja yang mempunyai prestasi. Faktor yang sangat penting dalam menunjang keberhasilan usaha suatu organisasi maupun perusahaan adalah produktifitas kerja karyawan. Produktifitas yang tinggi akan sangat menguntungkan baik bagi pengusaha maupun bagi karyawan terutama untuk kesejahteraannya.

Setiap perusahaan perlu memikirkan cara yang dapat digunakan untuk mengembangkan sumber daya manusianya agar dapat mendorong kemajuan bagi perusahaan dan bagaimana caranya agar karyawan tersebut memiliki produktifitas yang tinggi. Berbagai upaya yang dapat ditempuh oleh perusahaan adalah dengan cara melakukan pengembangan sumber daya manusia karyawan. Pentingnya pengembangan ini ditunjukkan untuk meningkatkan kualitas kerja dalam melakukan kegiatan di dalam perusahaan. Kualitas sumber daya karyawan ditingkatkan melalui kegiatan penilaian prestasi kerja karyawan 
yang digunakan sebagai alat ukur untuk mengetahui prestasi dan kemampuan karyawan. Hal ini dapat memotivasi karyawan untuk meningkatkan kinerja karyawan.

Perusahaan dapat berkontribusi dalam memberikan pelatihan terhadap karyawan. Pelatihan terhadap karyawan sangat berpengaruh dengan hasil kinerja karyawan untuk mengukur hasil kinerjanya. Pelatihan karyawan dilakukan dengan tujuan agar dapat meningkatkan kinerja. Pelatihan karyawan pun dapat memberikan efek yang baik kepada karyawan sehingga karyawan dapat mengembangkan diri dan mampu memahami beberapa hal seperti memahami perkembangan perusahaan, mudah memahami informasi yang disampaikan perusahaan dan memahami sistem atau prosedur yang digunakan perusahaan. Peran pelatihan yaitu bahwa fungsi pelatihan yang diharapkan dapat berjalan dengan baik, jika pelatihan menjalankan perannya dengan baik maka akan mendapatkan akreditasi atau citra yang baik didalam memberikan pengetahuan dan keterampilan karyawan.

Memberikan pelatihan karyawan juga pada kenyataannya dihadapkan pada beberapa masalah, seperti masalah kurikulum, program dan materinya. Perbedaan kemampuan setiap orang dalam menyerap materi dan pelatihan menjadikan tenaga pengajar harus mampu memahami dan menjalankan tugas secara profesional agar kualitas sumber daya manusia yang lulus dapat lebih baik dari sebelumnya.

Pelatihan dan pengembangan merupakan investasi organisasi yang penting dalam sumber daya manusia. Pelatihan melibatkan segenap sumber daya manusia untuk mendapatkan pengetahuan dan keterampilan pembelajaran sehingga mereka segera akan dapat menggunakannya dalam pekerjaan. Pada dasarnya, pelatihan diperlukan karena adanya kesenjangan antara keterampilan pekerja sekarang dengan keterampilan yang dibutuhkan untuk menempati posisi baru (Pakpahan, 2014)

Kinerja pegawai dalam suatu organisasi sangat dipengaruhi oleh disiplin pegawai. Apabila diantara pegawai sudah tidak melaksanakan kedisiplinan kerja, maka dapat dipastikan produktivitas kerja sangat diperlukan kedisiplinan dari para pegawai. Ketidakdisiplinan dan kedisiplinan dapat menjadi panutan orang lain. Jika lingkungan kerja semuanya disiplin, maka seorang pegawai akan ikut disiplin, tetapi jika lingkungan kerja organisasi tidak disiplin, maka mayoritas pegawai akan mengikutinya. Untuk itu, sangat sulit bagi lingkungan keja yang tidak disiplin tetapi ingin menerapkan kedisiplinan pegawai, karena lingkungan kerja akan menjadi panutan bagi para pegawai. Jadi, dapat disimpulkan bahwa disiplin pegawai merupakan perilaku seseorang sesuai peraturan, prosedur kerja yang ada. Disiplin merupakan sikap, tingkah laku, dan perbuatan yang sesuai dengan peraturan organisasi baik tertulis maupun tidak tertulis (Suwondo \& Sutanto, 2015)

Dalam konsep manajemen, penghargaan merupakan salah satu sarana untuk meningkatkan motivasi kinerja para pegawai. Metode ini dapat mengasosiasikan perbuatan serta tindakan seseorang dengan perasaan bahagia, senang dan biasanya akan melaksanakan perbuatan baik secara berulang-ulang. Penghargaan juga bertujuan agar seseorang menjadi semakin giat dalam usaha memperbaiki maupun meningkatkan yang telah dicapainya.

Penghargaan merupakan sarana pendidikan yang mudah dilaksanakan dan sangat menyenangkan bagi karyawan. Untuk itu, penghargaan dalan suatu proses pekerjaan sangat dibutuhkan keberadaannya sebagai motivasi demi meningkatkan kinerja para pegawai. Maksud dari pemberian penghargaan kepada pegawai adalah menjadi lebih giat dalam bekerja, guna memperbaiki atau mempertinggi prestasi kerja yang telah dicapainya. Dalam hal ini, karyawan menjadi lebih keras kemauannya untuk meningkatkan kinerja. Penghargaan merupakan penilaian bersifat positif terhadap pegawai 
Penghargaan merupakan ganjaran yang diberikan untuk memotivasi para karyawan agar produktivitasnya tinggi. Menurut Ramli (2019), penghargaan merupakan insentif yang mengaitkan bayaran atas dasar untuk dapat meningkatkan produktivitas para karyawan guna mencapai keunggulan yang kompetitif. Menurut Tangkuman (2015), penghargaan atau reward merupakan ganjaran yang diberikan untuk memotivasi para karyawan agar produktivitasnya tinggi. Penghargaan dapat berupa situasi, atau daftar verbal yang menghasilkan kepuasan atau meningkatkan kemungkinan mempelajari tindakan.

Pemberian penghargaan kepada karyawan yang berprestasi akan memberikan motivasi kepada karyawan untuk lebih meningkatkan produktivitasnya dalam bekerja. Dengan karyawan yang semakin produktif akan meningkatkan laba perusahaan. Selain itu, perusahaan dengan laba yang tinggi juga akan dapat meningkatkan kesejahteraan karyawannya. Pemberian penghargaan oleh perusahaan terhadap karyawan juga mempengaruhi kinerja dan produktifitas karyawan tersebut. Pemberian penghargaan ini secara positif menjadikan perusahaan akan lebih mudah untuk mencapai tujuannya.

Jika seorang karyawan tidak mendapatkan pelatihan dalam bidang pekerjaan yang digelutinya, maka karyawan tersebut akan sulit untuk memaksimalkan pekerjaan mereka karena terkendala pengetahuan. Apabila seorang karyawan tidak mempunyai disiplin kerja maka juga akan dapat merugikan perusahaan dengan kata lain kinerja mereka buruk. Selanjutnya, apabila seorang karyawan mendapat penghargaan dari perusahaan, misalnya promosi jabatan, bonus gaji dan lain-lain, maka karyawan tersebut akan termotivasi untuk terus meningkatkan kualitas kinerja karena menyangkut jenjang karir karyawan tersebut

\section{LANDASAN TEORI \\ Kinerja}

Suatu organisasi perusahaan didirikan karena mempunyai tujuan tertentu yang ingin dan harus dicapai. Dalam mencapai tujuannya setiap organisasi dipengaruhi perilaku organisasi. Salah satu kegiatan yang paling lazim dilakukan dalam organisasi kinerja karyawan, yaitu bagaimana melakukan segala sesuatu yang berhubungan dengan pekerjaan atau peranan dalam organisasi. Kinerja pegawai merupakan suatu hasil yang dicapai oleh pegawai tersebut dalam pekerjaanya menurut kriteria tertentu yang berlaku untuk suatu pekerjaan tertentu. Nurcahyani (2016) menjelaskan bahwa kinerja merupakan hasil pekerjaan yang dicapai karyawan berdasarkan persyaratan-persyaratan pekerjaan. Rimpulaeng (2014) menguraikan bahwa kinerja merupakan hasil kerja secara kualitas yang dicapai oleh seseorang karyawan dalam melaksanakan tugasnya sesuai dengan tanggung jawab yang diberikan. Kinerja adalah suatu hasil kerja yang dicapai seorang dalam melaksanakan tugastugas yang dibebeankan kepadanya yang didasarkan atas kecakapan, pengalaman dan kesungguhan serta waktu, sebagian besar organisasi, kinerja para karyawan individual merupakan faktor utama yang menentukan keberhasilan organisasi (Bolung et al., 2018)

\section{Pelatihan}

Pelatihan merupakan usaha mengurangi atau menghilangkan terjadinya kesenjangan antara kemampuan karyawan dengan yang dikehendaki organisasi. Usaha tersebut dilakukan melalui peningkatan kemampuan kerja yang dimiliki karyawan dengan cara menambah pengetahuan dan keterampilan serta merubah sikap. Karyawan merupakan kekayaan organisasi yang paling berharga, karena dengan segala potensi yang dimilikinya, karyawan dapat terus dilatih dan dikembangkan, sehingga dapat lebih berdaya guna, prestasinya 
menjadi semakin optimal untuk mencapai tujuan organisasi. Adanya kesenjangan antara kemampuan karyawan dengan yang dikehendaki organisasi, menyebabkan perlunya organisasi menjembatani kesenjangan tersebut, salah satu caranya dengan pelatihan. Dengan demikian diharapkan seluruh potensi yang dimiliki karyawan, yaitu pengetahuan, keterampilan dan sikap dapat ditingkatkan, akhirnya kesenjangan berkurang atau tidak terjadi lagi kesenjangan. Pelatihan bukanlah tujuan, melainkan suatu alat dari manajemen untuk mencapai tujuan perusahaan yang mana merupakan usaha dan tanggung jawab pimpinan tertinggi terhadap karyawan yang menjadi tanggung jawabnya. Mangkunegara (2016) mengemukakan bahwa pelatihan adalah suatu proses pendidikan jangka pendek yang mempergunakan prosedur sistematis dan terorganisir di mana pegawai nonmanagerial mempelajari pengetahuan dan keterampilan teknis dalam tujuan terbatas. Rahinnaya (2016) menyatakan bahwa Pelatihan adalah aktivitas - aktivitas yang di rancang untuk memberi para pembelajar pengetahuan dan keterampilan yang dibutuhkan untuk pekerjaan mereka saat ini. Bolung et al. (2018) mengemukakan pelatihan adalah setiap usaha untuk memperbaiki performansi pekerja pada suatu pekerjaan tertentu yang sedang menjadi tanggung jawabnya. Dengan adanya pelatihan akan dapat menimbulkan perubahan dalam kebiasaan bekerja, perubahan sikap, tingkah laku, keterampilan serta pengetahuan karyawan. Dan pelatihan tersebut harus dilakukan secara terus menerus. Pelatihan merupakan proses timbal balik yang bersifat membantu dan mereka yang dilatih harus aktif demi keberhasilan pelatihan tersebut agar tujuan perusahaan tercapai.

\section{Disiplin}

Pangarso (2016) menjelaskan bahwa disiplin merupakan suatu sikap menghormati, menghargai, patuh dan taat terhadap peraturan-peraturan yang berlaku baik yang tertulis maupun yang tidak tertulis serta sanggup menjalankannya dan tidak mengelak untuk menerima sanksi-sanksi apabila ia melanggar tugas dan wewenang yang diberikan kepadannya. Astutik (2017) mendefinisikan kedisiplinan adalah kesadaran dan kesediaan seseorang untuk mentaati semua peraturan dan norma-norma sosial yang ada dalam suatu organisasi pemerintah. Kesadaran adalah sikap seseorang yang secara sukarela mentaati semua peraturan dan sadar akan tugas dan tanggung jawabnya. Karyawan akan mematuhi / mengerjakan semua tugasnya dengan baik, bukan atas dasar paksaan. Kesediaan adalah suatu sikap, tingkah laku dan perbuatan seseorang yang sesuai dengan peraturan organisasi, baik yang tertulis maupun tidak tertulis. Hasibuan (2019) berpendapat bahwa disiplin kerja adalah alat yang digunakan oleh manajer untuk berkomunikasi dengan karyawan sehingga mereka mau untuk mengubah perilaku serta upaya untuk meningkatkan kesadaran dan kemauan seseorang untuk patuh dengan semua aturan perusahaan dan norma sosial yang berlaku. Tujuan utama disiplin adalah untuk meningkatkan hasil semaksimal mungkin dengan cara mencegah pemborosan waktu dan energi. Selain itu, disiplin mencoba untuk mencegah kerusakan atau kehilangan harta benda, mesin, peralatan, dan perlengkapan kerja yang disebabkan oleh ketidak hati-hatian, senda gurau atau pencurian. Disiplin mencoba mengatasi kesalahan dan keteledoran yang disebabkan karena kurang perhatian, ketidak mampuan dan keterlambatan. Disiplin berusaha mencoba permulaan kerja yang lambat atau terlalu awal mengakhiri kerja yang disebabkan karena keterlambatan. Disiplin juga berusaha untuk mengatasi perbedaan pendapat antara karyawan dan mencegah ketidak taatan yang disebabkan salah pengertian dan salah penafsiran. 


\section{Penghargaan}

Penghargaan merupakan sebuah bentuk apresiasi kepada suatu prestasi tertentu yang diberikan, baik oleh dan dari perorangan ataupun suatu lembaga yang biasanya diberikan dalam bentuk material atau ucapan. Dalam organisasi ada istilah insentif atau hadiah, yang merupakan suatu penghargaan dalam bentuk material atau non material yang diberikan oleh pihak pimpinan organisasi perusahaan kepada karyawan agar mereka bekerja dengan menjadikan modal motivasi yang tinggi dan berprestasi dalam mencapai tujuan-tujuan perusahaan atau organisasi. Kadarisman (2012) menjelaskan bahwa penghargaan adalah apa yang karyawan terima sebagai balasan dari pekerjaan yang diberikannya. Kevin Tangkuman et al. (2015), menguraikan bahwa penghargaan adalah usaha menumbuhkan perasaan diterima di lingkungan kerja, yang menyentuh aspek kompensasi dan aspek hubungan antara para pekerja yang satu dengan yang lainnya. Penghargaan adalah imbalan yang diberikan oleh perusahaan terhadap karyawannya atas pekerjaan yang telah dilakukannya, baik penghargaan yang bersifat intrinsik ataupun ekstrinsik (Prabu \& Wijayanti, 2016). Pemberian penghargaan atau reward bertujuan untuk meningkatkan produktivitas dan mempertahankan karyawan yang berprestasi agar tetap loyal kepada perusahaan. Pemberian sistem penghargaan dimaksudkan sebagai dorongan agar karyawan mau bekerja dengan lebih baik dan membangkitkan motivasi sehingga mendorong kinerja karyawan yang lebih baik.

\section{METODE PENELITIAN}

Penelitian ini menggunakan metode kuantitatif, metode yang menekankan aspek pengukuran secara obyektif terhadap fenomena sosial. Penelitian ini dilakukan di bank sinarmas kabupaten Bekasi. Sampel dalampenelitian ini adalah karyawan PT Bank Sinarmas di Kabupaten Bekasi yang berjumlah 65 responden. Metode pengumpulan data yang digunakan dalam penelitian ini, dengan cara menyebarkan angket kuesioner yang berisi tentang pernyataan mengenai pelatihan, disiplin, penghargaan dan kinerja kepada karyawan PT Bank Sinarmas di Kabupaten Bekasi dengan skala penilaian responden 1-5 menggunakan Skala Likert, dimana skala 1 (sangat tidak setuju) sampai dengan skala 5 (sangat setuju). Berdasarkan tujuan dari penelitian ini, metode yang digunakan menggunakan regresi linier berganda dengan bantuan alat analisis software SPSS. Langkah pertama dalam melakukan analisis pada penelitian ini adalah dengan menyebarkan kuisioner. Langkah kedua setelah menyebarkan kuisioner yaitu melakukan pengumpulan data dari hasil kuisioner yang telah disebarkan. Langkah ketiga kemudian dilakukan pengolahan data dengan menggunakan uji validitas, reliabilitas, uji asumsi klasik dan regesi linier berganda.

\section{HASIL DAN PEMBAHASAN}

\section{Uji Normalitas}

Berdasarkan hasil analisis data dengan menggunakan SPSS Versi 24, Uji Normalitas dapat dilihat pada lampiran dan hasilnya pada tabel berikut:

Tabel 1. One-Sample Kolmogorov-Smirnov Test

\begin{tabular}{llr} 
& \multicolumn{2}{c}{ Unstandardized Residual } \\
\hline N & & 65 \\
\hline Normal Parameters $^{\text {a,b }}$ & Mean &, 0000000 \\
\cline { 2 - 3 } & Std. Deviation & 2,73207271 \\
\hline
\end{tabular}




\begin{tabular}{lrr}
\multirow{2}{*}{ Most Extreme Differences } & Absolute &, 089 \\
\cline { 2 - 3 } & Positive &, 089 \\
\cline { 2 - 3 } & Negative &,- 080 \\
\hline Test Statistic &, 089 \\
\hline Asymp. Sig. (2-tailed) &, $200^{\text {c,d }}$ \\
\hline
\end{tabular}

Sumber : Data penelitian yang diolah, 2020

Berdasarkan hasil pengolahan data menunjukkan bahwa Sig. > 0,05. Demikian dapat disimpulkan bahwa variabel Pelatihan, Disiplin, Penghargaan dan Kinerja yang digunakan dalam penelitian ini adalah semuanya berdistribusi normal.

\section{Uji Multikolinearitas}

Uji Multikolinearitas digunakan untuk menguji apakah ditemukan adanya korelaso yang tinggi antar variabel independen. Model regresi yang baik seharusnya tidak terjadi korelasi yang tinggi di antara variabel bebas. Untuk mendekati ada tidaknya multikolinearitas umumnya dengan melihat nilai Tolerance dan VIF pada hasil regresi linier. Jika Tolerance lebih dari 0,1 dan VIF kurang dari 10, maka tidak terjadi multikolinearitas.

Tabel 2. Hasil Uji Multikolineritas

\begin{tabular}{ccccc}
\hline No. & Variabel & Tolerance & VIF & Keterangan \\
\hline 1. & Pelatihan & 0.866 & 1.155 & \\
\cline { 1 - 3 } 2. & Disiplin & 0.742 & 1.349 & Tidak ada Multikolinearias \\
\cline { 1 - 3 } 3. & Penghargaan & 0.717 & 1.395 & \\
\hline
\end{tabular}

Sumber: Data penelitian yang diolah, 2019

Dari tabel 2 dapat diketahui bahwa nilai Tolirance dari ketiga variabel independen lebih dari 0,1 dan VIP kurang dari 10. Artinya dapat disimpulkan bahwa dalam model regresi tidak terjadi masalah multikolinearitas.

\section{Uji Heteroskedastisitas}

Uji Heteroskedastisitas digunakan untuk menguji apakah dalam model regresi terjadi ketidaksamaan varian dari residual pada suatu pengamatan kepengamatan yang lain. Ada atau tidaknya heteroskedastisitas disini dilihat dengan melihat pola titik-titik pada scatterplots regresi yang dihasilkan melalui SPSS. Apabila pola membentuk pola tertentu, maka model regresi memiliki gejala heteroskedastisitas. Jika tidak ada pola yang jelas dengan titik-titik yang menyebar di atas dan di bawah angka nol dan pada sumbu Y, maka disimpulkan bebas heteroskedastisitas. Uji Heteroskedastisitas menghasilkan grafik pola penyebaran titik sebagai berikut: 


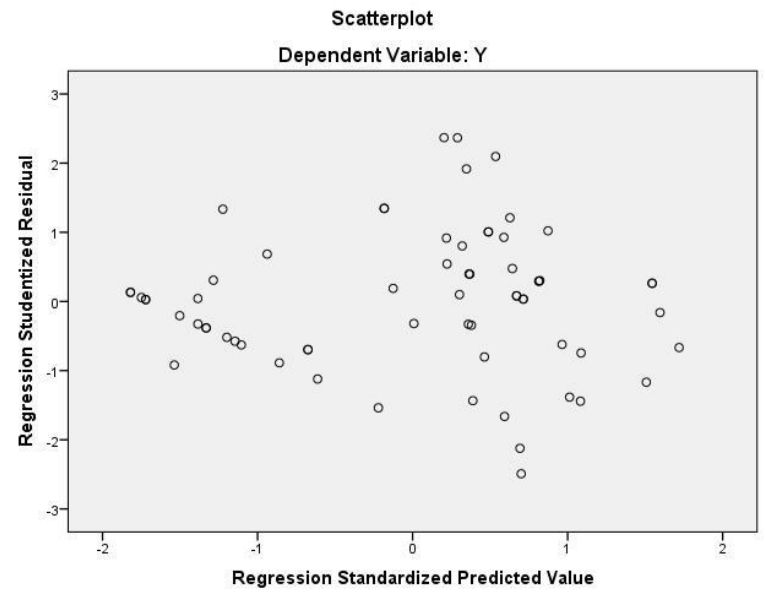

Gambar 1 Hasil Output Uji Heteroskedasitas

Hasil pengujian heteroskedastisitas menunjukkan bahwa titik-titik menyebar dengan pola yang tidak jelas di atas dan di bawah angka 0 pada sumbu $Y$, maka dapat disimpulkan bahwa tidak terjadi masalah heteroskedastisitas pada model regresi.

\section{Koefisien Determinasi $\mathbf{R}^{2}$}

Koefisien determinasi digunakaan untuk mengukur seberapa besar kontribusi variabel bebas yaitu Pelatihan, Disiplin, dan penghargaan) terhadap variabel terikat yaitu kinerja karyawan. Jika $\mathrm{R}^{2}$ semakin besar (mendekati satu), maka dapat dikatakan bahwa pengaruh variabel bebas pelatihan, disiplin, dan penghargaan adalah sebesar terhadap variabel terikat kinerja karyawan. Hal ini berarti model yang digunakan semakin kuat untuk menerangkan pengaruh variabel bebas terhadap variabel terikat dan demikian sebaliknya. Dari hasil perhitungan didapatkan nilai koefisien determinasi sebagai berikut :

Tabel 3. Hasil Uji Koefisien Determinasi Model Summary ${ }^{b}$

\begin{tabular}{lrrrrr} 
Model & $\mathrm{R}$ & R Square & Adjusted R Square & Std. Error of the Estimate \\
\hline 1 &, $724^{\mathrm{a}}$ &, 524 &, 501 & 2,798 \\
\hline a. Predictors: (Constant), PENGHARGAAN, PELATIHAN, DISIPLIN & \\
b. Dependent Variable: KINERJA
\end{tabular}

Berdasarkan tabel 3. dari hasil dari perhitungan dengan menggunakan SPSS, dapat diketahui bahwa determinasi (Adjusted $\mathrm{R}^{2)}$ yang diperoleh sebesar 0.501. Hal ini berarti $50,1 \%$ Pelatihan, Disiplin dan Penghargaan berpengaruh terhadap kinerja karyawan sedangkan sisanya sebesar 49,9\% dapat dijelaskan oleh variabel lain yang tidak diteliti dalam penelitian ini.

\section{Analisis Regresi Linear Berganda}

Perhitungan statistik dalam analisis regresi linear berganda yang digunakan dalam penelitian ini adalah dengan menggunakan software SPSS Versi 24. Analisis regresi linear berganda digunakan dalam penelitian ini dengan tujuan untuk mengetahui ada tidaknya pengaruh 
variabel bebas terhadap variabel terikat. Hasil regresi linear berganda adalah sebagai berikut:

Tabel 4. Hasil Regresi Linear Berganda

Coefficients $^{\mathrm{a}}$

\begin{tabular}{|c|c|c|c|c|c|c|}
\hline \multirow[b]{2}{*}{ Model } & & \multicolumn{2}{|c|}{ Unstandardized Coefficients } & \multirow{2}{*}{$\begin{array}{c}\text { Standardized } \\
\text { Coefficients } \\
\text { Beta } \\
\end{array}$} & \multirow[b]{2}{*}{$\mathrm{T}$} & \multirow[b]{2}{*}{ Sig. } \\
\hline & & $\mathrm{B}$ & Std. Error & & & \\
\hline \multirow[t]{4}{*}{1} & (Constant) & 1,135 & 4,893 & & ,232 & 817 \\
\hline & PELATIHAN &, 253 & ,094 & ,256 & 2,691 & 009 \\
\hline & DISIPLIN & ,281 & ,099 & ,292 & 2,850 &, 006 \\
\hline & PENGHARGAAN &, 433 &, 116 &, 389 & 3,727 &, 000 \\
\hline
\end{tabular}

Sumber: Data penelitian yang diolah, 2020

Berdasarkan output SPSS pada tabel 4, maka diperolah persamaan regresi sebagai berikut :

$$
Y=1,135 X+0,253 X_{1}+0,281 X_{2}+0,433 X_{3}
$$

Model tersebut menunjukan arti bahwa Konstanta $=1,135$. Jika variabel Pelatihan, Disiplin dan Penghargaan diasumsikan tetap, maka Kinerja karyawan meningkat 1.135. Nilai koefisien Pelatihan sebesar 0.253 menyatakan bahwa setiap terjadi kenaikan 1 skor untuk Pelatihan akan diikuti terjadinya kenaikan Kinerja karyawan sebesar 0.253. Nilai koefisiensi Disiplin menunjukan angka sebesar 0.281, menyatakan bahwa apabila terjadi kenaikan 1 skor untuk Disiplin akan diikuti dengan terjadi kenaikan Kinerja Karyawan sebesar 0.281. Nilai koefisiensi Penghargaan menunjukan angka sebesar 0.433, menyatakan bahwa apabila terjadi kenaikan 1 skor untuk Penghargaan akan diikuti dengan terjadi kenaikan Kinerja Karyawan sebesar 0.433

\section{Pembahasan}

Berdasarkan hasil pengujian secara statistik dapat dilihat bahwa secara parsial dapat dilihat bahwa Pelatihan berpengaruh positif dan signifikan terhadap kinerja karyawan, sedangkan disiplin berpengaruh positif dan signifikan terhadaap kinerja karyawan, dan penghargaan berpengaruh positif dan signifikan terhadap kinerja karyawan :

\section{Pengaruh Pelatihan terhadap Kinerja Karyawan}

Pengujian hipotesis $\left(\mathrm{H}_{1}\right)$ menunjukan terdapat pengaruh antara pelatihan terhadap kinerja karyawan. Serta berdasarkan uji statistik mengenai Pelatihan menunjukan nilai t sebesar 2.691 dengan signifikansi 0.009 yang berarti bahwa variabel pelatihan memiliki pengaruh yang positif terhadap kinerja karyawan. Karena $t_{\text {hitung }}>t_{\text {tabel }}$ atau $2.691>2.000$ artinya menunjukan bahwa pelatihan dapat mempengaruhi kinerja PT Bank Sinarmas di kabupaten Bekasi

\section{Pengaruh Disiplin terhadap Kinerja Karyawan}

Pengujian hipotesis $\left(\mathrm{H}_{2}\right)$ menunjukkan bahwa disiplin berpengaruh terhadap kinerja karyawan. Berdasarkan uji statistik yang telah dilakukan menunjukan bahwa nilai t 2.850 
dengan signifikansi 0.006 yang berarti bahwa Disiplin memiliki pengaruh positif terhadap kinerja karyawan. Karena thitung $<$ ttabel atau $2.850>2.000$. Hal ini menunjukan bahwa Disiplin berpengaruh terhadap Kinerja PT Bank Sinarmas di Kabupaten Bekasi.

\section{Pengaruh Penghargaan terhadap Kinerja Karyawan}

Pengujian hipotesis $\left(\mathrm{H}_{3}\right)$ menunjukan terdapat pengaruh antara penghargaan dan kinerja karyawan. Berdasarkan uji statistik mengenai penghargaan menunjukan nilai t sebesar 3.727 dengan signifikansi 0.000 yang berarti bahwa variabel pengawasan memiliki pengaruh yang positif terhadap kinerja pegawai. Karena thitung >ttabel atau $3.727>2.000$. Hal ini menunjukan bahwa Penghargaan dapat mempengaruhi Kinerja PT Bank Sinarmas di Kabupaten Bekasi.

\section{KESIMPULAN}

Hasil analisis mengenai faktor-faktor yang mempengaruhi kinerja karyawan menunjukkan bahwa faktor pelatihan, disiplin kerja dan penghargaan memiliki hubungan yang positif terhadap kinerja karyawan, yang ditunjukan dengan koefisien variabel independent bertanda positif. Berdasarkan hasil analisis mengenai faktor-faktor mengenai kinerja karyawan, nampak bahwa ketiga variabel yang dianalisis diketahui yang mempengaruhi kinerja karyawan adalah semua variabel independent. Kinerja karyawan yang masih perlu untuk ditingkatkan adalah pengetahuan kerja karyawan. Penguasaan lingkup pekerjaan yang dilakukan selama ini masih belum sepenuhnya dipahami oleh Sebagian karyawan. Peningkatan penguasaan lingkup pekerjaan dapat dilakukan dengan mengadakan pelatihan kepada karyawan. Pelatihan yang dilakukan secara periodik dapat meningkatkan ketrampilan dan pengetahuan karyawan dalam menjalankan pekerjaan.

\section{DAFTAR PUSTAKA}

Astutik, M. (2017). Pengaruh Disiplin Kerja Dan Budaya Organisasi Terhadap Kinerja Pegawai Sekretariat Dewan Perwakilan Rakyat Daerah Kabupaten Jombang. JBMP (Jurnal Bisnis, Manajemen Dan Perbankan), 2(2), 141-159.

Bolung, R. V., Moniharapon, S., \& Lumintang, G. G. (2018). Pengaruh Pelatihan Dan Kompensasi Terhadap Kinerja Pegawai Pada BPMPD Provinsi Sulawesi Utara. Jurnal EMBA: Jurnal Riset Ekonomi, Manajemen, Bisnis Dan Akuntansi, 6(3).

Hasibuan, J. S., \& Silvya, B. (2019). Pengaruh Disiplin Kerja dan Motivasi Terhadap Kinerja Karyawan. Prosiding Seminar Nasional USM, 2(1), 134-147.

Kadarisman, M. (2012). Manajemen Pengembangan Sumber Daya Manusia. In Rajawali Press. Jakarta.

Mangkunegara, A. A. A. P. (2016). Manajemen sumber daya manusia perusahaan. PT. Remaja Rosdakarya.

Nurcahyani, N. M., \& Adnyani, I. G. A. D. (2016). Pengaruh kompensasi dan motivasi terhadap kinerja karyawan dengan kepuasan kerja sebagai variabel intervening. E-Jurnal Manajemen, 5(1).

Pakpahan, E. S. (2014). Pengaruh Pendidikan dan Pelatihan terhadap Kinerja Pegawai (Studi pada Badan Kepegawaian Daerah Kota Malang). Jurnal Administrasi Publik, 2(1), 116121.

Pangarso, A., \& Susanti, P. I. (2016). Pengaruh disiplin kerja terhadap kinerja pegawai di biro pelayanan sosial dasar sekretariat daerah provinsi Jawa Barat. Jurnal Manajemen Teori 
Dan Terapan| Journal of Theory and Applied Management, 9(2).

Prabu, A. S., \& Wijayanti, D. T. (2016). Pengaruh penghargaan dan motivasi terhadap kinerja karyawan (Studi pada divisi penjualan PT. United Motors Center Suzuki Ahmad Yani, Surabaya). Jurnal Ekonomi Bisnis Dan Kewirausahaan, 5(2), 104-117.

Rahinnaya, R., \& Perdhana, M. S. (2016). ANALISIS PENGARUH PELATIHAN DAN PENGEMBANGAN, KOMPENSASI SERTA KOMPETENSI TERHADAP KINERJA KARYAWAN (Studi pada PT Pos Semarang). Fakultas Ekonomika dan Bisnis.

Ramli, M. (2019). PENGARUH REWARD DAN PUNISHMENT TERHADAP PENINGKATAN DISIPLIN KERJA KARYAWAN PADA PT. LONDON SUMATERA (PERUSAHAAN EKSPOR KARET) DI BULUKUMBA. MANDAR: Management Development and Applied Research Journal, 2(1), 8-16.

Rimpulaeng, K., \& Sepang, J. L. (2014). Motivasi Kerja, Komitmen Karyawan, dan Budaya Organisasi, Pengaruhnya terhadap Kinerja Karyawan PT. Gudang Garam Manado. Jurnal EMBA: Jurnal Riset Ekonomi, Manajemen, Bisnis Dan Akuntansi, 2(3).

Suwondo, D. I., \& Sutanto, E. M. (2015). Hubungan lingkungan kerja, disiplin kerja, dan kinerja karyawan. Jurnal Manajemen Dan Kewirausahaan, 17(2), 145-154.

Tangkuman, K., Tewal, B., \& Trang, I. (2015). Penilaian kinerja, reward, dan punishment terhadap kinerja karyawan pada PT. Pertamina (persero) cabang pemasaran suluttenggo. Jurnal EMBA: Jurnal Riset Ekonomi, Manajemen, Bisnis Dan Akuntansi, 3(2). 